\title{
Konflikt izraelsko-palestyński w latach 2006-2014 - analiza i bilans
}

\section{Israeli-Palestinian conflict in the years 2006-2014 - the analysis and the balance}

\section{Streszczenie:}

Konflikt izraelsko-palestyński to jeden z największych konfliktów we współczesnych stosunkach międzynarodowych. Jego złożoność sprawia, że jest problem który niezwykle trudno rozwiązać. W XXI wieku konflikt pogłębił się, a do eskalacji doszło po zwycięskich dla Hamasu wyborach parlamentarnych. Ugrupowanie umocniło swoją pozycję na palestyńskiej scenie politycznej, ale przysporzyło to Palestynie wewnętrznych i zewnętrznych. W kraju doszło do kryzysu politycznego spowodowanego konfliktem Hamasu z Fatahem. Izrael natomiast nie mógł zaakceptować nowo wybranej władzy. Na linii Hamas-Izrael dochodziło do coraz większych napięć, czego efektem były izraelskie operacje zbrojne przeprowadzone w latach 2006-2014. Przyszłość konfliktu izraelsko-palestyńskiego wydaje się być trudna, a szanse na pokój znikome.

Słowa kluczowe: Konflikt izraelsko-palestyński, Bliski Wschód, bezpieczeństwo międzynarodowe, konflikty zbrojne

\footnotetext{
Abstract:

Israeli-Palestinian conflict is one of the greatest conflicts in contemporary international relations. Its complexity makes it a problem which is extremely
} 
Marcin Godziński - Konflikt izraelsko-palestyński...

difficult to resolve. In the twenty-first century, the conflict deepened, and the escalation came after Hamas winning the elections. Grouping strengthened its position on the Palestinian political scene, but it has caused inside and outside Palestine. In the country there was a political crisis caused by the conflict between Hamas and Fatah. Israel couldn't accept the newly elected government. On the line Hamas-Israel occurred to increasing tensions, which resulted in Israeli military operations carried out in the years 2006-2014. The future of the Israeli-Palestinian conflict seems to be difficult, and the chances for peace are faintly.

Keywords: Israeli-Palestinian conflict, the Middle East, international security, military conflicts

\section{Wstęp}

Konflikt izraelsko-palestyński, to jeden z największych konfliktów we współczesnych stosunkach międzynarodowych. Trwa nieprzerwanie od ponad sześćdziesięciu lat i stanowi ogromne wyzwanie dla społeczności międzynarodowej. Na przestrzeni dziesięcioleci podejmowano już wiele prób jego rozwiązania, jednak żadna nie przyniosła oczekiwanych efektów. Wszelkie mediacje i próby negocjacji stają w martwym punkcie z uwagi na złożoność problemu i warunki jakie obie strony muszą spełnić, by mógł zapanować trwały pokój. W XXI wieku wciąż podejmowane są wysiłki na rzecz stworzenia państwa palestyńskiego, ale kolejne konflikty między Palestyną i Izraelem hamują proces pokojowy. Obie strony wielokrotnie deklarowały chęć wznawiania rozmów pokojowych, jednak kryteria jakie stawiają przed sobą sprawiają, że negocjacje nieustannie kończą się fiaskiem.

W latach 2006-2014 można było mówić o eskalacji konfliktu. Analiza wydarzeń w Palestynie od wyborów parlamentarnych z 2006 roku do końca 2014 roku pozwala obiektywnie ocenić perspektywy na przyszłość i odpowiedzieć na pytanie, czy rozwiązanie konfliktu w najbliższych latach jest możliwe? Jest także ważna z punktu widzenia bilansu wydarzeń toczących się trochę w cieniu Arabskiej Wiosny. 
W ostatnich latach konflikt izraelsko-palestyński został przysłonięty przez wybuch licznych rewolucji na Bliskim Wschodzie. Szczególnie wydarzenia toczące się w Syrii odegrały znaczącą rolę w regionie. Nie można jednak zapominać, że od tego jak rozgrywać będzie się konflikt izraelsko-palestyński zależy przyszłość Bliskiego Wschodu. Problem palestyński wpływa na poziom bezpieczeństwa w obszarze MENA. Jest to zagadnienie szczególnie istotne we współczesnym, dynamicznie zmieniającym się środowisku międzynarodowym. W obliczu wyzwań związanych z implikacjami Arabskiej Wiosny kwestia palestyńska powinna jawić się jako jedno z fundamentalnych wyzwań nie tylko dla państw regionu, ale przede wszystkim dla mocarstw, które angażują się w politykę bliskowschodnią. W XXI będzie czasem uwydatniania się i nasilania istniejącego konfliktu. Już pierwsze lata nowego tysiąclecia pokazały, że w Palestynie następuje zmiana układu sił na scenie politycznej. Niewątpliwie umocniła się pozycja Hamasu, jako ugrupowania politycznego reprezentującego interesy palestyńskiego społeczeństwa. Doszło do rywalizacji z Fatahem, który od porażki w wyborach parlamentarnych podejmuje próby pojednania z Hamasem, z różnym skutkiem. Konflikt polityczny w Palestynie wpłynął negatywnie na proces pokojowy i pozwolił Izraelowi na realizowanie własnej polityki kosztem Palestyńczyków. Brak jedności na palestyńskiej scenie politycznej pogłębił istniejący kryzys i zmniejszył szanse na szybki pokój w regionie.

\section{Geneza konfliktu i czasy współczesne}

Historia konfliktu izraelsko-palestyńskiego sięga początku XX wieku, kiedy to doszło do kilku znaczących wydarzeń na Bliskim Wschodzie. Niewątpliwie jednym z nich było wystosowanie Deklaracji Balfoura w 1917 roku$^{1}$. Po I wojnie światowej na Bliskim Wschodzie

\footnotetext{
${ }^{1}$ Deklaracja Balfoura - list wysłany 2 listopada 1917 przez lorda Arthura Jamesa Balfoura - ówczesnego brytyjskiego ministra spraw zagranicznych do barona Wal-
} 
Marcin Godziński - Konflikt izraelsko-palestyński...

zmienił się układ sił. Ku upadkowi chyliło się Imperium Osmańskie, a jeszcze w trakcie trwania wojny zawarto tajne porozumienie Sykes Picot, pomiędzy rządami Wielkiej Brytanii i Francji, którego celem był podział regionu na strefę wpływów - brytyjskich i francuskich. Dodatkowo na terytorium Palestyny napływały kolejne fale żydowskich migrantów. W latach 1919-1923 miała miejsce tzw. trzecia alija². Poprzednie dwie miały miejsce w latach 1881-1903 oraz 1904-1913. Wydarzenia te wpłynęły negatywnie na relacje arabsko-żydowskie i stały się katalizatorem napięć w kolejnych latach. 1 lipca 1920 roku Palestyna stała się terytorium mandatowym Wielkiej Brytanii. Opór przeciwko władzom mandatowym i osadnictwu żydowskiemu nasilał się z każdym kolejnym rokiem. Do pierwszych starć i zamieszek doszło już w 1920 i 1921 roku. Kolejne powstania miały miejsce w 1929, 1933 i w latach 1936-19393. Wybuch II wojny światowej zakończył powstanie arabskie, ale nie zakończył konfliktu w Palestynie. Zarówno Arabowie, jak i Żydzi przyczyniali się do eskalacji napięć. Od 1945 roku żydowskie ugrupowania paramilitarne dokonywały aktów terrorystycznych. Organizacje takie jak Hagana, Irgun oraz Lehi dopuszczały się ataków antybrytyjskich. W 1946 roku Irgun dokonał jeden z największych zamachów terrorystycznego w ówczesnej historii regionu. Celem ataku był hotel Króla Dawida w Jerozolimie. W latach 19471948 w Palestynie toczyła się wojna domowa. 29 listopada 1947 roku Zgromadzenie Ogólne ONZ przyjęło projekt podziału Palestyny na dwa państwa: żydowskie i arabskie, jednak rezolucję nr 181 odrzuciły państwa arabskie i Najwyższy Komitet Arabski w Palestynie. Ponadto Wielka Brytania planowała wycofać się z Palestyny, ale decyzję o zakończeniu mandatu chciała ogłosić w połowie grudnia 1947 roku. Brytyjczycy wiedzieli o planach Ligi Arabskiej, która przygotowywała

thera Rothschilda. Dokument ten był deklaracją brytyjskiego rządu wspierającą żydowskie starania o utworzenie w Palestynie żydowskiej siedziby narodowej.

${ }^{2}$ Alije - żydowskie migracje do Palestyny. Alije miały miejsce w latach: 18811903, 1904-1913, 1919-1923, 1924- 1931, 1931-1940, 1941-1947, a także współcześnie (proces ten nie jest objęty ramami czasowymi).

3 D. Madeyska, Historia współczesna świata arabskiego, Warszawa 2008, s. 15. 
się do wszczęcia działań zbrojnych przeciwko Izraelowi, gdyby doszło do realizacji rezolucji ONZ. Walki między Arabami i Żydami trwały od końca listopada 1947 roku aż do 15 maja 1948 roku, kiedy to Izrael proklamował swoją niepodległość. W międzyczasie Wielka Brytania starała się nie angażować w konflikt między zwaśnionymi stronami, powoli wycofując się z terytorium Palestyny. W nocy z 14 na 15 maja 1948 roku, po upłynięciu terminu zniesienia brytyjskiego mandatu, Izrael ogłosił swoją suwerenność. 0 świcie 15 maja siedem arabskich państw (Egipt, Irak, Syria, Liban, Transjordania, Jemen i Arabia Saudyjska) dokonało inwazji na nowo powstałe państwo ${ }^{4}$. Pierwsza wojna izraelsko-arabska toczyła się w latach 1948-1949 i zakończyła się klęską państw arabskich. W wyniku konfliktu około 75\% Palestyny znalazło się w granicach Izraela ${ }^{5}$. Od pierwszej wojny izraelsko-arabskiej minęło już ponad sześćdziesiąt lat, jednak konflikt o Palestynę wciąż przypomina o swoim istnieniu. Na przestrzeni dziesięcioleci dochodziło jeszcze do kilku wojen izraelsko-arabskich. W 1967 roku miała miejsce wojna sześciodniowa, w wyniku której kraje arabskie poniosły ogromną klęskę, doznając znaczących strat militarnych i terytorialnych ${ }^{6}$. Serię arabskich porażek w konflikcie z Izraelem podtrzymała również wojna Jom Kipur z 1973 roku. Przyszłość Palestyny wciąż pozostawała niejasna, a nadzieje na porozumienie wydawały się nikłe. W 1987 roku w Palestynie wybuchła Intifada, podczas której wykrystalizował się Muzułmański Ruch Oporu, znany jako Hamas. Ugrupowanie to działało w Palestynie już wcześniej, ale w zupełnie w innej formie i pod inną nazwą. Początki organizacji sięgają lat 70., kiedy to stworzono ruch religijny o nazwie al-Mudżamma.

Al-Mudżammat ul-Islami - bo tak brzmi pełna nazwa tego ugrupowania - to stowarzyszenie które miało prowadzić propagandę religijną i aktywność o charakterze społecznym. Swoją działalność organizacja rozpoczęła w 1973. W 1978 została oficjalnie zarejestrowana

\footnotetext{
${ }^{4}$ Ibid., s.24.

${ }^{5}$ A. Hourani, Historia Arabów. Narody i cywilizacje, Gdańsk 2002, s. 357.

${ }^{6}$ Encyklopedia PWN, Warszawa 1997, s. 328.
} 
Marcin Godziński - Konflikt izraelsko-palestyński...

przez izraelskie władze, a na jej czele stanął charyzmatyczny członek Bractwa Muzułmańskiego - szajch Ahmad Jasin. Pierwotnie ugrupowanie miało być konkurencją dla Organizacji Wyzwolenia Palestyny. Izrael chciał w ten sposób osłabić pozycję OWP na palestyńskiej scenie politycznej. Jednak z czasem al-Mudżamma ulegała coraz większej radykalizacji, w dużej mierze pod wpływem samych Palestyńczyków, którzy domagali się walki z okupantem. Hamas powstał na fundamentach al-Mudżammy, a przywództwo nad powstaniem pozwoliło mu na konsolidację i rozwój. Ugrupowanie dysponuje kilkoma pionami, które świadczą o rozbudowanej strukturze organizacji oraz o różnych celach jej aktywności. Jednym z najważniejszych pionów jest pion socjalny - Da'wa. Jest on odpowiedzialny za przeprowadzanie akcji humanitarnych oraz charytatywnych inicjowanych przez Muzułmański Ruch Oporu. Da'wa jest najbardziej rozbudowanym pionem w całej strukturze Hamasu. To z niego płyną środki finansowe na system oświaty, finansowany od najniższego do najwyższego szczebla edukacji. Da’wa finansuje również opiekę zdrowotną oraz system świadczeń w postaci zapomóg. Jednak Muzułmański Ruch Oporu stał się znany głównie dzięki zamachom terrorystycznym przeprowadzonym na terenie Izraela od 1994 roku.

Powyższe informacje o Hamasie są o tyle istotne, że w XXI wieku ugrupowanie to będzie miało ogromne znaczenie na palestyńskiej scenie politycznej, będzie także stroną konfliktu izraelsko-palestyńskiego. Nim Muzułmański Ruch Oporu rozpoczął działalność polityczną uznawany był za jedną z najgroźniejszych organizacji terrorystycznych na świecie. Hamas odpowiadał za co najmniej kilkadziesiąt ataków dokonanych $\mathrm{w}$ różnych izraelskich miastach na przestrzeni zaledwie kilku lat.

W tym czasie podejmowano próby pokojowego rozwiązania konfliktu. W sierpniu 1994 roku Izrael zaczął przekazywać palestyńskim władzom swoje kompetencje samorządowe, kontynuowano także zawieranie dokumentów stanowiących podstawę prawną dla istnienia Autonomii Palestyńskiej. Po zawarciu porozumienia z Oslo, w 1995 
roku przeprowadzono kolejne rozmowy, których efektem było porozumienie określane jako Oslo II $^{7}$. Śmierć premiera Icchaka Rabina nie zmieniła polityki Izraela, Szymon Peres również dążył do zbliżenia i pokojowego zakończenia konfliktu. Zmiana nastąpiła po przejęciu władzy przez Beniamina Netanjahu. Mimo, że oficjalnie mówiło się o kontynuacji procesu koncyliacji, to nowy rząd izraelski daleki był od popierania idei dwóch niepodległych państw. Netanjahu był skłonny przekazać władzę samorządową Palestyńczykom, ale wykluczał ustępstwa w sprawie istniejących sporów. Zmianie uległa polityka izraelskiego osadnictwa i stosunek do palestyńskich uchodźców. Taki stan rzeczy prowadził do eskalacji napięć. Po amerykańskiej interwencji dyplomatycznej w 1998 roku podpisano memorandum w Wye River, na mocy którego Izrael miał przekazać terytoria pod kontrolę Autonomii Palestyńskiej, zwolnić kilkuset więźniów palestyńskich, umożliwić Palestyńczykom swobodny przejazd ze Strefy Gazy na Zachodni Brzeg Jordanu, władze palestyńskie miały natomiast zwiększyć wysiłki na rzecz walki z terroryzmem ${ }^{8}$. Podpisanie przez Netanjahu porozumienia podważyło jego pozycję wśród izraelskiej prawicy. Ponadto Kneset wstrzymał realizację zawartego wcześniej dokumentu. Pogorszyło to zarówno relacje izraelsko-palestyńskie, jak i sytuacje wewnętrzną w kraju. Podjęto decyzję o przeprowadzeniu przyspieszonych wyborów, w wyniku których władzę przejął Ehud Barak. Choć Barak deklarował chęć kontynuacji dialogu, to fiasko rozmów w Camp David w 2000 roku wzmogło kolejne napięcia9 28 września 2000 roku wybuchła II intifada. Próby mediacji nie przyniosły efektów, a rozmowy między stronami zostały uznane za bezcelowe. W listopadzie 2000 roku Ehud Barak ogłosił decyzję o rezygnacji i rozpisaniu nowych wyborów na premiera. Jego następcą został Ariel Szaron, dla którego od rozmów pokojowych z przedstawicielami Autonomii Palestyńskiej ważniejsza była kwestia bezpieczeństwa Izraela.

\footnotetext{
${ }^{7}$ K. Bojko, Izrael a aspiracje Palestyńczyków 1987-2006, Warszawa 2006, s. 102.

8 Ibid., s. 131-132.

${ }^{9}$ Ibid., s. 158-159.
} 
Marcin Godziński - Konflikt izraelsko-palestyński...

Szaron stosował zaostrzoną politykę wobec Palestyńczyków, a sytuację pogarszały zamachy dokonywane przez Hamas i Islamski Dżihad. $\mathrm{Na}$ eskalację konfliktu wpływały też liczne działania zbrojne Izraelskich sił przeprowadzane na terytorium Autonomii Palestyńskiej. 12 września 2001 roku izraelskie Siły Obrony przeprowadziły operację wojskową mającą na celu wyeliminowanie terrorystów. Ostrzeliwano siedzibę palestyńskich sił bezpieczeństwa w Dżeninie, a kilka dni później izraelska armia wkroczyła do Ramallah. W latach 20022005 Izrael przeprowadził jeszcze inne operacje zbrojne, m.in. Operację Arka Noego, Tarcza Obronna, Zdecydowana Ścieżka oraz Operację Tęcza. Początek XXI wieku przyniósł we wzajemnych relacjach ogromne napięcia. Ponadto na palestyńskiej scenie politycznej doszło do poważnych zmian, głównie w wyniku śmierci Jasira Arafata.

\section{Konflikt izraelsko-palestyński w latach 2006-2014}

W 2006 roku zwycięstwo w wyborach parlamentarnych odniósł Hamas, zdobywając 76 mandatów, dzięki czemu ugrupowanie to było główną siłą polityczną na palestyńskiej scenie politycznej. Niewątpliwie sukces Hamasu miał wpływ na sytuację wewnętrzną w Palestynie. Jednak kryzys polityczny i brak jedności między Hamasem i Fatahem nie wpływał pozytywnie na relacje z Izraelem i próby rozwiązania konfliktu. Fatah w wyborach parlamentarnych był zdecydowanym przegranym, ponieważ zdobył jedynie 46 mandatów. Choć w marcu 2006 roku ukonstytuował się nowy gabinet z Ismailem Haniją na czele, to bardzo szybko ujawnił się konflikt na linii Hanija - Abbas. Napięcia między politykami skłoniły prezydenta Abbasa do podjęcia wyjątkowych środków ostrożności, w postaci wprowadzenia stanu wyjątkowego, rozwiązania parlamentu i dymisji rządu Haniji. Powołano nowy gabinet z Salamem Fajadem na czele. W Palestynie rozpoczął się okres dwuwładzy: Fatah rządził na Zachodnim Brzegu Jordanu, a Ha- 
mas w Strefie Gazy ${ }^{10}$. Palestyńczycy byli podzieleni, nie koncentrowali się na walce z Izraelem, tylko prowadzili walkę między sobą. Kryzys polityczny pogłębiał się coraz bardziej, co osłabiało szanse na pokój. Po przejęciu władzy przez Hamas władze izraelskie rozpoczęły blokadę Strefy Gazy, ograniczając dostawy prądu i wody, a także wstrzymując import i eksport towarów. Krok ten doprowadził do katastrofy humanitarnej w regionie. Hamas w odpowiedzi na te działania rozpoczął budowę tuneli podziemnych łączących Strefę Gazy z Egiptem. Nastroje antyizraelskie wśród Palestyńczyków nasilały się, represje prowadzone przez Izrael rodziły chęć odwetu. 27 grudnia 2008 roku izraelskie siły obrony rozpoczęły operację wojskową pod kryptonimem Płynny Ołów, której celem była likwidacja infrastruktury Hamasu w Strefie Gazy. Podczas blokady Gazy Hamas oraz inne ugrupowania antyizraelskie zwiększyły liczbę rakiet wystrzeliwanych w kierunku Izraela. Pociski moździerzowe spadały głównie na południowy Izrael, nie powodując żadnych znaczących zniszczeń ani strat. Mimo to Izrael odpowiadał bombardowaniami w latach 2007-2008.

19 czerwca 2008 roku rozpoczęło się zawieszenie broni między stronami konfliktu. Żadna z nich nie przestrzegała jednak ustalonych wcześniej warunków. Hamas w zamian za zakończenie ataków rakietowych domagał się zakończenia blokady Strefy Gazy. Izrael oskarżał ugrupowanie o dalsze ataki rakietowe. 18 grudnia 2008 roku zbrojne skrzydło Muzułmańskiego Ruchu Oporu ogłosiło, że Izrael naruszył rozejm 185 razy. 19 grudnia rozejm zakończył się a Hamas zapowiedział wznowienie ataków na Izrael. Najpierw wystrzelono z terytorium Gazy dwie rakiety w kierunku Izraela, a potem przeprowadzono zamach w Srdot. W odpowiedzi na ataki Izrael w dniu 20 grudnia zbombardował Strefę Gazy. W kolejnych dniach dochodziło do ataków z obu stron. 24 grudnia Muzułmański Ruchu Oporu wystrzelił ponad 80 rakiet, co spotkało się z oburzeniem izraelskiego społeczeństwa. Wydarzenia te stały się tłem operacji Płynny ołów, która w krajach

10 S. Niedziela, Kwestia palestyńska a eskalacja konfliktu 2008-2009, „Zeszyty Naukowe Akademii Marynarki Wojennej”, Gdynia 2009, nr 3, s. 72. 
Marcin Godziński - Konflikt izraelsko-palestyński...

arabskich określana jest jako Masakra Gazy. W działaniach zbrojnych prowadzonych od 27 grudnia 2008 roku do 18 stycznia 2009 zginęło ponad 1300 osób11. Ponad 5300 zostało rannych. Po zakończeniu walk i podpisaniu rozejmu Izrael oskarżany był o zbrodnie wojenne. 24 stycznia 2009 roku Hamas oznajmił, że przystąpi do rozmów z Izraelem dopiero po otworzeniu granic. W lutym 2009 roku Międzynarodowy Trybunał Karny w Hadze rozważał postawienie zarzutu dokonania zbrodni wojennych przez izraelskich dowódców. Sprawa wróciła we wrześniu 2009 po publikacji raportu Richarda Goldstone’a przewodniczącego komisji Rady Praw Człowieka Organizacji Narodów Zjednoczonych ${ }^{12}$. Dokument ten co prawda oskarżał obie strony konfliktu o zbrodnie, ale to Izrael podjął jego krytykę uznając go za nieobiektywny. W 2011 roku autor skorygował swój raport obarczając winą za ogromną liczbę ofiar jedynie Hamas. W międzyczasie Izrael korzystał na istniejących w Palestynie podziałach politycznych, dzięki którym mógł bez większych problemów kolonizować Zachodni Brzeg Jordanu. Impas między Fatahem i Hamasem został jednak ostatecznie przełamany i po wielomiesięcznym okresie dyplomatycznego zawieszenia osiągnięto kompromis. Było to bardzo ważne, ponieważ na Bliskim Wschodzie trwała w tym czasie Arabska Wiosna, która nie ominęła również Palestyny ${ }^{13}$. Demonstracje odbywały się w Gazie oraz Ramallah. Brak porozumienia mógłby doprowadzić do eskalacji kryzysu politycznego albo obalenia palestyńskiej władzy, gdyby nie doszło zakończenia sporu między ugrupowaniami. Porozumienie z kwietnia 2011 roku miało zakończyć wojnę palestyńsko-palestyńską i powołanie wspólnego gabinetu. Plan pojednania politycznego nie powstrzymał ataków rakietowych na Izrael. W 2011 doszło do 680

11 S. Zuhur, Gaza, Israel, Hamas and the lost calm of operation Cast Lead, „Middle East Policy", Waszyngton 2009, nr 16, s. 41.

${ }^{12} \mathrm{R}$. Goldstone, Report of the United Nations Fact-Finding Mission on the Gaza Conflict, http://www2.ohchr. org/english/bodies/hrcouncil/docs/12session/A-HRC12-48.pdf (dostęp: 7.03.2016).

13 D. Wach, Wpływ Arabskiej Wiosny na sytuację w Palestynie i Izraelu, „Kultura i polityka", Kraków 2013, nr 11, s. 116-120. 
takich ataków. W 2012 roku najważniejszym wydarzeniem w konflikcie izraelsko-palestyńskim była kolejna operacja zbrojna przeprowadzona przez Izrael. 5 listopada 2012 roku, po ostrzałach rakietowych prowadzonych przez stronę palestyńską, izraelscy żołnierze zabili młodego Palestyńczyka który przekroczył granicę. Wydarzenia te po raz kolejny doprowadziły do eskalacji konfliktu. Palestyńczycy zdetonowali pułapkę na okolicznej drodze. 10 listopada 2012 roku Hamas ostrzelał samochód należący do izraelskich sił zbrojnych. W odwecie wojsko izraelskie dokonało ataku na Gazę. W dniach 14-17 listopada 2012 roku przeprowadzono operację zbrojną pod kryptonimem Filar Obrony. Po zakończeniu działań zbrojnych obie strony ogłosiły się zwycięzcami. Izraelski rząd ogłosił, że zrealizował wszystkie cele swojej operacji, natomiast Hamas oświadczył że wszystkie jego żądania zostały spełnione i dzięki atakowi rakietowemu Izrael dobrze zastanowi się nim znów zaatakuje Gazę ${ }^{14}$ Z $\mathrm{Z}$ punktu widzenia propagandowego Izrael po kolejnym ataku na Strefę Gazy stracił wyraźne poparcie społeczności międzynarodowej. Palestyna odniosła natomiast pewien symboliczny sukces, ponieważ pod koniec listopada 2012 otrzymała status nieczłonkowskiego państwa obserwatora od Zgromadzenia Ogólnego Narodów Zjednoczonych. Był to następny krok do realizacji idei niepodległej Palestyny. W 2011 roku Palestyna została oficjalnym członkiem UNESCO. Podobne kroki podjął w 2014 roku Parlament Europejski przyjmując uchwałę o uznaniu palestyńskiej państwowości. Jedynym warunkiem jest uznanie swojego istnienia przez obie strony konfliktu. 4 stycznia 2013 roku prezydent Mahmud Abbas przekształcił Autonomię Palestyńską w państwo Palestynę. 17 stycznia 2013 roku sekretarz generalny ONZ Ban Ki-moon zaapelował o zatrzymanie robót budowlanych na Zachodnim Brzegu Jordanu i potwierdził, że plan budowy izraelskich osiedli jest nielegalny i niezgodny z prawem międzynarodowym. Mimo to minister obro-

\footnotetext{
${ }^{14}$ E. Kam, Following the operation: The balance between the two sides, [w:] In the aftermath of Operation Pillar of Defense. The Gaza Strip, November 2012, S. Brom (red.), Tel Awiw 2012, s. 17.
} 
Marcin Godziński - Konflikt izraelsko-palestyński...

ny Izraela Ehud Barak zatwierdził 8 lutego 2013 roku plan budowy nowych osiedli. W sierpniu 2013 roku dzięki amerykańskim mediacjom Izrael i Palestyny wróciły po kilku latach do rozmów pokojowych. Jednak już z góry można było zakładać, że przełom nie nastąpi. Porozumienie nie było możliwe ze względu na dwie istotnie kwestie przyszłe granice państwa palestyńskiego oraz izraelskie osadnictwo.

W 2014 roku po raz kolejny doszło do eskalacji konfliktu. Było to spowodowane splotem kilku wydarzeń. Po pierwsze, załamaniu uległy rozmów pokojowych. Po drugie, doszło do porwania i zabójstwie trzech izraelskich nastolatków i jednego Palestyńczyka. Po trzecie, Hamas wybudował nowe tunele podziemne. Po czwarte, zwiększyła się liczba wzajemnych ataków Hamasu i izraelskiej armii. 8 lipca 2014 roku izraelskie siły obrony rozpoczęły operację pod kryptonimem Ochronny Brzeg, która zakończyła się 26 sierpnia 2014 roku. Był to największy konflikt w Strefie Gazy od czasów operacji Płynny Ołów. Według szacunków podczas izraelskiej interwencji zginęło ponad 2000 Palestyńczyków a ponad 10000 zostało rannych ${ }^{15}$. Po kolejnym izraelskim ataku coraz częściej mówiło się o tym, że w Palestynie może dojść do wybuchu trzeciej intifady. Konflikt na przestrzeni lat 2006-2014 wyraźnie zyskał na sile. Podczas ostatniej interwencji zbrojnej większość ofiar stanowili cywile, podobnie jak w przypadku ataku z lat 2008-2009. W wyniku bombardowań zniszczeniu uległa także znaczącą cześć infrastruktury wodno-kanalizacyjnej, co groziło pogorszeniu sytuacji humanitarnej. Już wcześniej woda z kranu w większości przypadków była niezdatna do spożycia. Zniszczeniu uległy również sieci energetyczne, ograniczając dostawy prądu. Oprócz wymienionych wyżej skutków, wśród zniszczeń należy wymienić również placówki edukacyjne oraz szpitale. Sytuacja nie sprzyjała prowadzeniu kolejnych negocjacji, jednak w październiku 2014 roku sekretarz stanu USA John Kerry oraz prezydent Egiptu Abd al-Fatah as-Sisi zaapelowali o wznowienie rozmów pokojowych. W listopadzie

15 Death toll from Gaza offensive topped 2,310, http://www.maannews.com/Con tent.aspx?id=751290 (dostęp: 7.03.2016). 
2014 Ban Ki-moon wezwał Izrael do zakończenia okupacji, zakończenia oblężenia Strefy Gazy i podjęcia kroków w celu rozwiązania konfliktu. Wszelkie próby rozwiązania konfliktu izraelsko-palestyńskiego w latach 2006-2014 okazały się nieskuteczne. Mimo rosnącego poparcia dla Palestyny wśród społeczności międzynarodowej trudno było zaobserwować szanse na rozwiązanie tego toczącego się od dziesięcioleci konfliktu. Jednym z warunków zawarcia pokoju jest powrót Palestyny do granic sprzed 1967 roku - jest to kryterium nierealne do spełnienia ze względu na nieustępliwość Izraela w tej kwestii. Również sprawa rozbudowy izraelskich osiedli stanowi problem, którego władze izraelskie nie chcą rozwiązać. Zakończenie konfliktu wymaga od obu stron ustępstw, ale żadna ze stron nie jest gotowa do ich dokonania. Kolejnym warunkiem wydaje się zniesienie blokady Strefy Gazy, która na przestrzeni 8 lat ucierpiała w wyniku ciągłych operacji zbrojnych. Izraelskie naloty zniszczyły wiele fabryk pogłębiając poziom bezrobocia i ubóstwa $\mathrm{w}$ regionie. Po wygranych przez Hamas wyborach ugrupowanie rozpoczęło walkę $\mathrm{z}$ bezrobociem, czego skutkiem było stworzenie 13000 nowych miejsc pracy w Strefie Gazy. Jednak okazało się to niewystarczające w obliczu nowych wyzwań i zagrożeń ekonomicznych związanych z konfliktem w ostatnich latach. Wśród implikacji oprócz strat ekonomicznych i ludnościowych, ważnym aspektem stało się rozczłonkowanie społeczności palestyńskiej, do jakiego doszło w wyniku prowadzonych operacji zbrojnych. W Gazie miało miejsce naruszenie struktur i więzi społecznych. Sąsiedzi przestali być sąsiadami, rodziny uległy rozdzieleniu, ludzie stali się uchodźcami a ich dobytek uległ zniszczeniu ${ }^{16}$.

\section{Wnioski}

Lata 2006-2014 były dla relacji izraelsko-palestyńskich niezwykle trudnymi. Ze względu na liczne konflikty zbrojne należy ocenić je negatywnie. W okresie tym nie nastąpił przełom we wzajemnych stosun-

16 E. Jasiewicz, Podpalić Gazę, Warszawa 2011, s. 98. 
Marcin Godziński - Konflikt izraelsko-palestyński...

kach. Jedynym pozytywnym aspektem wydaje się zmiana sposobu postrzegania palestyńskich praw narodowych przez społeczność międzynarodową. Palestyna przez kilka lat zyskała spore poparcie, choć ma ono wymiar bardziej symboliczny. Palestyński establishment może dążyć jednak do jednostronnego proklamowania niepodległości. Obustronne uznanie wymagać będzie ustępstw i ogromnego zaangażowania podmiotów międzynarodowych. Co istotne, instytucje międzynarodowe nie zwiększyły swojego zaangażowana politycznego i dyplomatycznego na tyle by skłonić Izrael do ustępstw. Również strona palestyńska nie jest do nich skłonna. Wygranym w konflikcie jest niewątpliwie Hamas, który najpierw dzięki zwycięstwu politycznemu umocnił się, a także zyskał poparcie po kolejnych izraelskich interwencjach. Każdy kolejny atak Izraela umacniał Muzułmański Ruch Oporu i osłabiał idee pokojowego rozwiązania konfliktu. Mechanizm konfliktu izraelsko-palestyńskiego jest bardzo prosty - przemoc rodzi przemoc. Każdy atak rodzi odwet. Izrael nie ponosząc żadnych dotkliwych strat podejmuje operacje zbrojne o rozmiarach niewspółmiernych do wyrządzonych krzywd. Władze izraelskie ulegają ogromnej presji społecznej. Z jednej strony społeczeństwa obu podmiotów są już zmęczone toczącym się tyle lat konfliktem, z drugiej jednak strony nie są w stanie zapomnieć wyrządzonych sobie szkód. W ten oto sposób nakręca się spirala nienawiści. Jest to błędne koło, które wydaje się nie do zatrzymania w najbliższych latach. Pokój na Bliskim Wschodzie nie będzie możliwy bez poważnych kompromisów. Ze strony Izraela oznaczałoby to ewakuację osadników z Zachodniego Brzegu Jordanu oraz poniesienie ogromnych kosztów rekompensat. Ponadto należałoby rozwiązać kwestie przynależności Jerozolimy. Status tego miasta, to jeden z najbardziej drażliwych aspektów konfliktu. Od 1967 roku wschodnia, arabska cześć miasta jest okupowana i zgodnie z rezolucją Rady Bezpieczeństwa nr 242 powinna być zwrócona Arabom. Palestyna z kolei musiałaby wykluczyć ze sceny politycznej Hamas i odciąć się od jego działalności. Powyższe warunki są niemożliwe do spełnienia przez strony konfliktu. W związku z tym konflikt w per- 
spektywie wieloletniej wydaje się nierozwiązalny, a każde próby jego zakończenia skazane są na niepowodzenie.

\section{Bibliografia:}

Bojko K., Izrael a aspiracje Palestyńczyków 1987-2006, Warszawa 2006.

Encyklopedia PWN, Warszawa 1997.

Goldstone R., Report of the United Nations Fact-Finding Mission on the Gaza Conflict, http://www2.ohchr.org/english/bodies/hrcouncil/docs/12session /A-HRC-12-48.pdf.

Hourani A., Historia Arabów. Narody i cywilizacje, Gdańsk 2002.

Jasiewicz E., Podpalić Gazę, Warszawa 2011.

Kam E., Following the operation: The balance between the two sides, [w:] In the aftermath of Operation Pillar of Defense. The Gaza Strip, S. Brom (red.), Tel Awiw 2012.

Madeyska D., Historia wspótczesna świata arabskiego, Warszawa 2008.

Ministry: Death toll from Gaza offensive topped 2,310, http://www.maan news.com/ Content. aspx?id=751290.

Niedziela S., Kwestia palestyńska a eskalacja konfliktu 2008-2009, „Zeszyty Naukowe Akademii Marynarki Wojennej", Gdynia 2009, nr 3.

Wach D., Wpływ Arabskiej Wiosny na sytuację w Palestynie i Izraelu, „Kultura i polityka", Kraków 2013, nr 11.

Zuhur S., Gaza, Israel, Hamas and the lost calm of operation Cast Lead, [w:] „Middle East Policy”, Waszyngton 2009, nr 16. 